\title{
Evidentiary Considerations In Civil Cases
}

Lynn McLain

University of Baltimore, lmclain@ubalt.edu

Follow this and additional works at: http://scholarworks.law.ubalt.edu/all_fac

Part of the Evidence Commons, and the Legal Education Commons

\section{Recommended Citation}

Lynn McLain, Evidentiary Considerations In Civil Cases, (2000).

Available at: http://scholarworks.law.ubalt.edu/all_fac/919

This Article is brought to you for free and open access by the Faculty Scholarship at ScholarWorks@University of Baltimore School of Law. It has been accepted for inclusion in All Faculty Scholarship by an authorized administrator of ScholarWorks@University of Baltimore School of Law. For more information, please contact snolan@ubalt.edu. 


\section{Evidentiary Considerations in Civil Cases \\ Maryland Judicial Institute \\ March 17, 2000 \\ Lynn McLain}

\section{Character Evidence}

A. General Rule of Inadmissibility

\begin{tabular}{|c|c|}
\hline $\begin{array}{l}5-404 \text { (a) (1 st clause) } \\
\text { \& } \\
5-404 \text { (b) (1st clause): }\end{array}$ & $\begin{array}{l}\text { Character evidence is inadmissible to prove propensity -- } \\
\text { that a person acted in conformity } \\
\text { with his or her character on a particular occasion. }\end{array}$ \\
\hline
\end{tabular}

B. When Admissible

1. For impeachment (to show likelihood to lie),

$\underline{\text { Reputation Opinion Specific Instances }}$

proof of character traits for truthfulness

Yes Yes Only on cross of

and veracity, of any witness who has testified

(404(a)(3)) and rehabilitation of witness

character witness

(3405(a)) (But see also

who has been impeached by certain methods

Rules 5-608 and 5-609).

2. As substantive proof for purpose

other than proving propensity

a. Civil and criminal cases by

either party when character is

Yes Yes Yes

directly in issue ("essential

element of charge, claim, or

defense") (5-405(b)) (very rare, e.g.,

defamation, when truth is a defense)

b. Proof of other crimes or acts to

show only motive, etc. (5-404(b));

No

Yes

or acts by or reputation of victim,

generally

if known to $D$, to show D's

state of mind. (This other purpose

must be relevant to the case; don't

lose sight of 5-401 and 5-403.)

3. As substantive proof of propensity to

act in conformity with character and

past conduct: only criminal cases

a. In criminal cases, D may choose to

put his/her character in issue as

circumstantial proof of innocence

(then prosecution can rebut) (5-404(a)(1))

Yes Yes Only on cross of

character witness

$(5-405(a))$

b. Character of victim where D

Yes $\quad$ Yes

Only on cross of character

claims self-defense (see 5-404(a)(2))

witness (5-405(a)) (but see

2.b. above)

c. Note: HABIT evidence is admissible under Rule 5-406.

d. Note special nules for persons alleging sexual assault (5-412) and, in federal court, for persons sued for or charged with sexual assault (FRE 413-415) 
I. Character Evidence (for the text of the referenced rules, see infra pp. 12-16)

A. Admissible either as substantive evidence (Rules 5-404 through 5-406) or only as to credibility (impeachment or rehabilitation, Rules 5-608, 5-609, and 5-616).

\section{B. "The propensity rule" and its exceptions.}

1. "The propensity rule" generally excludes evidence of a person's other acts or a person's character or character trait to show that the person acted "in character" on the occasion at issue in the case. Rule 5-404(a)(1) and (b).

EXAMPLE: Plaintiff sues for severe injuries she alleges were caused by defendant's driving his truck through a red light.

a. Evidence that the plaintiff or the defendant is generally a bad driver is offered to show that the plaintiff or the defendant drove badly this time. Ruling:

b. Evidence that either one has driven through other red lights at other times is offered. Ruling:

[But, as to criminal cases, see Sessoms v. State, Md. (Sept. Term, 1999, No. 68, Jan. 11, 2000) where the Court of Appeals reversed the trial court's exclusion of evidence that the rape prosecutrix's brother was accused of robbing a third party hours after the alleged rape. Judge Cathell, writing for the court, stated:

We hold that the test for admitting other crimes evidence in criminal proceedings enunciated in Faulkner generally does not apply to crimes, wrongs, or acts committed by someone other than a criminal defendant. ${ }^{* * *}$ Because this rule is premised upon protecting an accused from undue prejudice, it does not apply to exclude other crimes evidence involving alleged actions by others testifying in the criminal proceedings. This is especially so when the evidence is crucial to the defense in a criminal proceeding and concerns impeachment of a witness with a possible prejudice, bias, interest, or motive to falsely testify.

Judge Wilner, dissenting, joined by Judges Rodowsky and Raker, would have affirmed the trial judge's decision as an appropriate exercise of discretion under Rule 5-403. The brother already had been impeached by his prior convictions for robbery, including one the day after the alleged rape.

2. Exceptions to the propensity rule are carved out in several Rules.

a. Evidence of repeated, similar acts that are specific enough to constitute an individual's habit or a business or other organization's routine practice is admissible as substantive evidence to prove that 
the person or organization acted in accordance with that routine on the occasion in question at trial. Rule 5-406.

EXAMPLE: Plaintiff's husband's testimony that he has been her passenger many times and she always buckles her seat belt before starting her car engine is offered to show that she buckled it on the day of the accident in question. Ruling:

b. Limited exceptions in criminal cases only, regarding reputation or opinion evidence of the accused's or the victim's pertinent character trait, as substantive evidence. Rule 5-404(a)(1)(A) and (B) and (2).

c. Exceptions for impeachment: evidence of a person's prior convictions (Rule 5-609), prior bad acts not resulting in conviction (Rule 5-608(b)) and opinion or reputation evidence regarding that person's bad character trait for truthfulness and veracity (Rule 5$608(a)(1) \&(3)(A))$, are admissible to prove that the person either a witness (Rule 5-404(a)(1)(C)) or a hearsay declarant (see Rule 5-806) - acted "in character" and lied in the testimony or statement admitted into evidence at trial. Rule 5-616(a)(6) and (b)(5) \& (6).

EXAMPLE: Plaintiff testified to the accident and to her injuries.

i. $\quad$ May she be cross-examined about her 1995 conviction for grand larceny? Ruling:

ii. About her having been fired for stealing from her employer? Ruling:

iii. May the defense call a character witness to testify to the plaintiff's bad reputation for truthfulness, or to the witness's opinion that the plaintiff is generally a liar? Ruling:

iv. May the character witness testify as to whether he or she believes the plaintiff's testimony in the case to be truthful? Ruling:

d. Exception for rehabilitation: a witness whose credibility has been impeached in such a way as to constitute an attack on the witness's character for truthfulness (usually one or more of the three methods in c. above, but the trial judge may find that, e.g., a particular impeachment by a prior inconsistent statement amounted to such an attack) may be rehabilitated by reputation or opinion evidence as to the witness's good character trait for truthfulness and veracity. Rules 5-608(a)(2) and (3)(A), 5-404(a)(1)(C), and 5-616(c)(3). 
EXAMPLE: After the impeachment in c.i., ii., or iii. above, may plaintiff call a character witness who will téstify to plaintiff's good reputation for truthfulness, or that, in the character witness's opinion, the plaintiff is generally a truthful person? Ruling:

\section{Admission of character evidence to prove something other than propensity.}

1. Specific prior instances to show motive, opportunity, intent, common scheme or plan, preparation, knowledge, identity, or absence of mistake or accident with regard to the act at issue at trial. Rule 5-404(b).

EXAMPLE a: May plaintiff prove that the defendant had just robbed a bank and was fleeing from the scene, to show why he would be likely to run a red light? Ruling:

EXAMPLE $b$ : If plaintiff alleges that defendant purposely ran into her, may plaintiff testify that she had recently reported him to their employer for sexual harassment? Ruling:

2. Reputation testimony, opinion testimony, or evidence of specific instances, to prove a person's character or character trait when it is an "essential element of a [criminal] charge, [civil] claim, or defense...." Rule 5405(b). Specific instances are allowed because someone's character must be proven, as an element. Therefore, the most probative - and the most time-consuming-method of proof is permitted.

EXAMPLE a: Plaintiff alleges that Defendant-Parent negligently entrusted the family truck to Driver-Teenager. May Plaintiff prove reputation of Teenager as a bad driver, and/or specific instances of Teenager's prior reckless driving, known to Defendant-Parent?

Ruling:

EXAMPLE b: Plaintiff sues Defendant for slander for telling Plaintiffs prospective landlord that Plaintiff was a "druggie." Defendant defends by alleging truth. May Defendant offer:

(i) Reputation and opinion testimony that Plaintiff abuses drugs? Ruling:

(ii) Evidence of specific instances of Plaintiff's using illegal drugs? Ruling:

D. Methods of proof when "character witnesses" testify (in civil or criminal cases, as to a principal witness's truthfulness and veracity, under Rule 5-608(a); and, in criminal cases, under Rule 5-404(a)(1)(A) and (B)).

1. Direct examination: reputation or opinion testimony, but not specific instances. Rules 5-405(a) and 608(a)(1), (2), and (3). 
2. Cross-examination: character witness may be asked about knowledge of specific instances of the principal witness's conduct that would lead to a reputation or opinion different than that to which the character witness testified. Rules 5-405(a) and 5-608(a)(4).

EXAMPLE: Assume that the Plaintiff has testified and is being impeached by a character witness.

a. Direct examination of reputation witness: proponent establishes that the character witness and the Plaintiff are members of the same community (residential, work, school, etc.); that Plaintiff has a reputation in that community as to character for truthfulness; and that that reputation is bad.

b. Direct examination of opinion witness: proponent establishes that the character witness has a "reasonable basis" for having an opinion regarding Plaintiff's character for truthfulness, e.g., (at least from July 1, 1994, until the Court of Appeals' August 31, 1999 decision in Jensen v. State) "I've worked next to her on the assembly line for $5 \frac{1}{2}$ years. We take our lunch and cigarette breaks together." "In my opinion, she is not a truthful person." Compare, e.g., Durkin v. State, 284 Md. 445, 453, 397 A.2d 600 (1979) (police officer who had brief encounter with witness when witness had made larceny report, which officer concluded was false, lacked sufficient basis for his opinion as to witness's truthfulness to be admissible) with Barnes v. State, $57 \mathrm{Md}$. App. 50, 57-60, 468 A.2d 1040 (1984) (character witness had adequate basis for opinion when she had known individual well for last two years, had been acquainted with her for several years before that, and had interviewed her several times to verify addresses and confirm leads). But see d.-f. infra.

c. Cross-examination of either, as to specific instances inconsistent with the accuracy of the reputation or the opinion, e.g., "Did you know (or have you heard) that in Plaintiff's night school class the professor made an arithmetical error in Plaintiff's favor, and Plaintiff voluntarily came forward to tell the professor so that the professor could lower her grade?" The questioner may not provide extrinsic evidence of this specific instance, which is admissible only for the limited purpose of impeaching the character witness's testimony.

d. Md. Cts. \& Jud. Proc. Code Ann. $§ 9-115$, adopted in 1971, permits opinion testimony by a character witness "who has an adequate basis for forming an opinion as to another person's character." Before the adoption of Title 5, Hemingway $v$. State, 76 Md. App. 127, 543 A.2d 879 (1988), had found reversible error when a trial judge restricted a defense character witness to 
testifying only to "the length of time he had known [the homicide victim] and his bald conclusion as to [the victim's] reputation for violence."

Judge Karwacki, writing for the Court of Special Appeals and relying on language by Chief Judge Gilbert in a 1975 case, held that the trial judge should have permitted the defense to elicit from its witness the specific matters on which the witness based his opinion, first, so as to "convince the trial judge that the witness possesses an adequate basis for forming an opinion as to another person's character." $76 \mathrm{Md}$. App. At 134. Secondly, Hemingway held that the jury also should hear this evidence:

This does not mean, however, that the basis for the character witness's opinion, if admitted, has no relevance to the weight ascribed to that opinion by the jury. Clearly, the bald conclusion of the witness without any reason to support it hardly commends the opinion for serious consideration by the trier of the fact.

Id. at 135 .

Thus, Hemingway mandated the courts' permitting the character witness to state what it was that led him or her to form the opinion to which the witness wished to testify.

e. Hemingway v. State was overruled by Title 5, in an effort to keep the direct testimony of a character witness short and sweet, i.e., to limit it to reputation or opinion.

It was believed undesirable to open up side issues as to whether specific instances that led the character witness to form an opinion occurred or not -- particularly when the character evidence is tangential, anyway. (The Rules permit specific instances to be proved on direct when character is an "essential element of a charge, claim, or defense." See C.2. supra, p. 4.)

Indeed, if one could testify to the specific instances that led to one's opinion, the opinion testimony would be superfluous and inadmissible under Rule 5-701, as unhelpful to the jury.

FRE 608 is rather obtusely written. Md. Rule 5-608 was re-written in an effort to clarify, but not depart substantively from FRE 608 (except that the Md. Rule rejects one federal case [as well as two 19th century Maryland cases] that permits character witnesses to testify to whether they believe the other witness's trial testimony).

For example, Md. Rule 5-608(a)(3)(B) explicitly states that the character witness on direct "may give a reasonable basis for 
testimony as to reputation or an opinion ... , but may not testify as to specific acts of truthfulness or untruthfulness. ..." This is declarative of the federal case law construing the federal rule.

The Federal Rule advisory committee's note provides that opinion testimony ought in general to "be confined to the nature and extent of observation and acquaintance upon which the opinion is based." Fed. R. Evid. 405 advisory committee's note. The Maryland Reporter's Note provides that " $t \mathrm{t}]$ he Committee envisions 'reasonable basis' evidence as covering such matters as how long the witnesses have been acquainted, under what circumstances, etc."

Jensen V. State, 355 Md. 692, 708 n.6, 736 A.2d 307 (1999). The "etc.," though meant to refer to matters of the same type as those listed, has caused problems, in that it has been expansively construed. See id. (f. infra).

f. But Jensen, $355 \mathrm{Md} .692$ (1999), has blurred the line. There the Court of Appeals (over a dissent on this point by Judge Chasanow) found that the trial court had erred in not permitting a defense character witness to explain, in front of the jury, that the reason she was of the opinion that one of the defendant's cohorts, a key State's witness, was a "compulsive liar," was because he told her "inconsistent stories about different things."

The trial judge had permitted her to testify before the jury to how long she had known the State's witness and how often she spoke with him.' It heard her testimony about "inconsistent

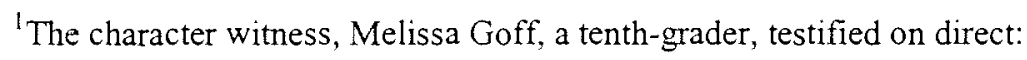

DEFENSE ATT'Y: Could you tell the jury, if you know, if you're familiar with Brian Wooldridge?

GOFF: Yes, I am.

Q: Okay, and how are you familiar with Brian Wooldridge?

A: I've known him for a while.

Q: You say a while?

A: I guess about a year, even a little longer.

Q: Now, is this a year before this incident or a year up to now?

A: I guess a year before.

Q: And during that particular year, how many times did you meet in a week?

A: I guess once a week. 
stories" outside the hearing of the jury, ${ }^{2}$ before permitting her to

Q: Have you ever spoken to Mr. Wooldridge on the phone?

A: Yes, I have

Q: And how many times have you spoken with him on the phone?

A: I usually speak to him every day.

Q: Okay, and when was that?

A: While he was out of school.

Q: And when was that?

A: I don't remember the exact months.

Q: And for what period of time did you speak to him every day-a week, two weeks, a month?

A: I guess for about a month. Yeah, a month.

Q: Okay, and do you have an opinion as to his veracity to tell the truth?

STATE'S ATTORNEY: Objection, Your Honor.

THE COURT: Sustained. Come forward, please, counsel. (Bench conference.)

STATE'S ATTORNEY: Insufficient, Your Honor.

THE COURT: Here's what I'm going to do. I am going to excuse the jury, and I am going to conduct -have counsel conduct an examination out of the presence of the jury. I don't believe at this stage you've yet established that basis for her opinion, all right? Thank you.

(The jury was excused from the courtroom.)

355 Md. at 695-96.

${ }^{2}$ THE COURT: Now, I sustained that objection on the basis that I conclude at this point there's not been an adequate basis for that opinion to be given, but ... I'll give you the opportunity at least to attempt to establish that basiś while we're out of the presence of the jury.

DEFENSE ATT'Y: In general, what would you talk about on the phone during that year that you knew him?

A: Just things, but he liked to talk about-I guess regular things that kids or normal teenagers would talk about to each other.

Q: Would he tell you inconsistent stories about different things? 
testify to her opinion in front of the jury. ${ }^{3}$
A: Yes.
Q: Objection, Your Honor.
THE COURT: Sustained.

["A lot of the stories that he told me didn't add up, saying that-one day he would tell me something that happened on that day and then a couple of days later he would tell me something else that had happened on that day that wouldn't have been able to happen if what he said before was true." Goff added that this happened "repeatedly." Jensen v. State, Md. App., Sept. Term, 1997, No. 1768, at 14 (unreported), rev'd, 355 Md. 692].

THE COURT: Under the circumstances, it seems to me that testimony given by Ms. Goff supports a basis from the information for her perception of these conversations for giving evidence as to the truthfulness or not of Mr. Wooldridge, and I'm going to allow this course of examination to continue.

(The jury returned to the courtroom).

$355 \mathrm{Md}$. at 697.

${ }^{3}$ DEFENSE ATT'Y: Do you have an opinion about Mr. Wooldridge's veracity to tell the truth?
A: Yes, um-
Q: What is that opinion?
A: I think that he's a compulsive liar.
Q: What do you base that opinion on?

STATE'S ATT'Y: Objection.

THE COURT: Sustained.

355 Md. at 697.

At the bench, the State argued that the defense had already laid the foundation and elicited the desired opinion, adding: "It's our position that those are specific instances (inaudible). He's done what he's been allowed to do under the rules, and that is (inaudible) opinion, and I don't think he should be allowed to go any further." In response, defense counsel claimed that "telling stories over and over again" was "not a specific act, that's an opinion." The trial court noted that Rule 5-608(a)(3)(B) prohibits a character witness from testifying about specific instances of truthfulness or untruthfulness and reasoned that any response would be "sort of a continuum of events . . . no more than a number of specific events tied together, which I think will create the same mischief as is intended to be prevented by the rule. ..." When defense counsel asserted that "the jury has a right to know what the basis is," the court declared, "No, I don't think that's it at all. I think you've gotten out of this witness on the subject what the rule intends for you to be able to get."

Md. App. opinion at 15. 
In the majority opinion authored by Judge Raker, the Court held that the procedure was an erroneous abuse of discretion. ${ }^{4}$ It rejected the State's argument that "reasonable basis evidence properly is limited to how long and under what circumstances the witnesses have been acquainted." $355 \mathrm{Md}$. at $696 .^{5}$ The majority characterized the excluded evidence as "not evidence of "specific instances," id. at 700, which it said would not be permitted on direct.

${ }^{4}$ The majority found the error to be harmless, in light of overwhelming evidence of the defendant's guilt. Chief Judge Bell, joined by Judge Eldridge, dissented, on the ground that the error was so serious as to be reversible.

${ }^{5}$ Judge Chasanow, concurring and dissenting, concluded, on the other hand:

It is quite clear that [Md. Rule 5-608(a)(3)(B)] is intended to allow the character witness to express the reasonable basis for arriving at an opinion, not the reasonable basis for the opinion arrived at.

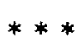

In order for a character witness to testify about the untruthful character or bad reputation for truthfulness of another witness, the character witness should establish a basis of knowledge.

In the instant case, the testimony at issue was that "[a] lot of the stories that he told me didn't add up" and "one day he would tell me something that happened on that day and then a couple days later he would tell me something [absolutely inconsistent with the first version]." This testimony is far more analogous to the prohibited specific acts of untruthfulness than to the permissible basis for knowledge of the witness's character. I do not believe the trial judge abused his discretion in prohibiting this testimony.

$355 \mathrm{Md}$. at $722,724-26$ (emphasis added).

The Court of Special Appeals similarly reasoned:

As we previously indicated, the substance of Goff's testimony in chambers was that Wooldridge "repeatedly" told her things that turned out to be untrue. From appellant's perspective, this amounted to a general statement about Wooldridge's character. From the trial court's perspective, however, Goff's testimony concerned a pattern of conduct that was predicated on numerous specific occurrences. Because Rule 5-608 permits, but does not mandate, introduction of evidence about the basis of the witness's belief, the trial court properly weighed the value of Goff's testimony in establishing how she formed her opinion against the danger that the jury would interpret her testimony as merely a summary of instances of dishonesty, introduced in lieu of a detailed description of each instance.

It is clear from the record that the trial court was persuaded that the jury would perceive Goff's testimony as a "continuum" of specific events. Nonetheless, the court permitted the witness to tell the jury about the extent of her contact with appellant over a period of time. This testimony, if believed, indicated that Goff's testimony was not a "bald conclusion".... Indeed, Goff's description of how long, and under what circumstances, she had known Wooldridge provided the jury with an ample basis to evaluate her opinion. Therefore, we perceive no abuse of discretion. ...

Md. App. opinion at 19. 
The majority acknowledged that "Rule 5-608 unquestionably intended to modify Maryland law, in particular, Hemingway v. State, 76 Md. App. 127, 543 A.2d 879 (1988), to the extent that specific instances of truthfulness or untruthfulness were not admissible on direct examination of a witness." $355 \mathrm{Md}$. at 706. As the majority aptly explained:

Maryland's Rule 608(a)(3)(B) is based on Federal Rule of Evidence 608(b), which in turn is related to Federal Rule of Evidence 405(b) on specific instances evidence. The advisory committee's note to Federal Rule 405 explains that although specific instances are the most convincing character evidence, that type of evidence also "possesses the greatest capacity to arouse prejudice, to confuse, to surprise, and to consume time." See also COURT OF APPEALS OF MARYLAND STANDING Committee on Rules of Practice and Procedure, Proposed Title 5 OF THE MARYLAND RULES OF PROCEDURE: EVIDENCE § 5-608 Reporter's Note (Subcommittee Draft 1991) (on file with Committee) (explaining that "routinely permitting such proof would distract and unduly influence juries and create too many time-consuming side issues."). As these notes suggest, once a witness testifies to a specific instance, the jury's focus necessarily turns to whether in fact that particular event occurred and the circumstances surrounding that event.

Id. at 699-700 (emphasis added). Yet the majority concluded:

In contrast, because [the character witness's] statement that [the State's witness] often told her mutually inconsistent stories spoke to a general trait and not to particular occasions on which he lied, it would not serve to distract and confuse the jury, nor would it consume time by altering the focus of the trial to other particular events.

Id. at 700 .

Quaere as to what happens, under this ruling, to the scope of cross? Must not the opposing counsel be permitted to probe into the specific "inconsistent stories," if counsel believes that will show them to be insubstantial? The scope of cross becomes much broader than simply asking about specific instances that did not go to form the witness's opinion, but would lead to the opposite opinion -- which is all that FRE 608(a) permits and that this writer understood that Rule 5-608(a)(4) was intended to permit.

The Jensen majority states:

It is fair to infer from the Rule and its history that the committee felt that a character witness was entitled to some latitude in informing the jury as to the basis for an opinion, so long as that person avoids venturing into the troublesome area of specific instances. Permitting such latitude allows the witness, within reason, to offer something to the jury bevond a bare conclusion that the witness "is a truthful person" or "is not a truthful person." Accordingly, we hold that the trial court 
abused its discretion in restricting Goff's testimony to a description of her acquaintance with Wooldridge and her conclusion that he was a "compulsive liar."

Id. at 708 (emphasis added; footnotes omitted). The difficult question is, what is that "something more"? Where is the line between "something more" and too much of "something more," i.e., "specific instances"? Judge Raker discussed the Jensen character witness's proffered testimony as follows:

[She testified to] Wooldridge's tendency to tell mutually inconsistent stories, i.e., his general tendency to be untruthful. Nor was her testimony "no more than a number of specific events tied together." She was not testifying as to several particular instances of conduct; she was testifying as to a general behavior pattern which was the basis for her opinion that Wooldridge was untruthful.

Id. at 699 .

Interestingly, both Hemingway and Jensen involved character witnesses helpful to the accused. But if a criminal accused testifies and thus subjects himself or herself to unfavorable character witness's testimony regarding the accused's truthfulness, Jensen would permit the State's witness to testify to "something more" than opinion. And, clearly, Jensen applies to 5-608(a) character witnesses in civil cases.

But what are the implications of Jensen, if any, as to Md. Rule 5-405? Hemingway involved a 5-405-type witness, and was discussed identically in the Rules Committee as to 5-405 and 5608. The Rules Committee's position was the same as to 5-405 as it was as to 5-608, but unlike Rule 5-608, Md. Rule 5-405 is identical, verbatim, to Federal Rule 405. If Jensen applies to Rule $5-405$, if an accused opens the door under Rule 5-404(a)(1) to evidence of his or her character trait pertinent to guilt or innocence, the direct of the State's character witnesses also will be broader.

\section{E. Text of the Referenced Rules}

\section{RULE 5-404. CHARACTER EVIDENCE NOT ADMISSIBLE TO PROVE CONDUCT; EXCEPTIONS; OTHER CRIMES}

(a) Character Evidence Generally.

(1) In General. Evidence of a person's character or a trait of character is not admissible for the purpose of proving action in conformity therewith on a particular occasion, except:

(A) Character of accused: Evidence of a pertinent trait of character of an accused offered by the accused, or by the prosecution to rebut the same; 
(B) Character of Victim. Evidence of a pertinent trait of character of the victim of the crime offered by an accused or by the prosecution to rebut the same, or evidence of a character trait of peacefulness of the victim offered by the prosecution in a homicide case to rebut evidence that the victim was the first aggressor;

(C) Character of Witness. Evidence of the character of a witness with regard to credibility, as provided in Rules 5-607, 5-608, and 5-609.

(2) Definitions. For purposes of subsections (a)(1)(A) and (B) of this Rule, "accused" means a defendant in a criminal case and a child alleged to be delinquent in an action in juvenile court, and for purposes of subsection $(\mathrm{a})(\mathrm{l})(\mathrm{B})$, "crime" includes a delinquent act as defined by Code, Courts Article, $\S 3-801$.

(b) Other Crimes, Wrongs, or Acts. Evidence of other crimes, wrongs, or acts is not admissible to prove the character of a person in order to show action in conformity therewith. It may, however, be admissible for purposes, such as proof of motive, opportunity, intent, preparation, common scheme or plan, knowledge, identity, or absence of mistake or accident.

\section{RULE 5-405. METHODS OF PROVING CHARACTER}

(a) Reputation or Opinion. In all cases in which evidence of character or a trait of character of a person is admissible, proof may be made by testimony as to reputation or by testimony in the form of an opinion. On cross-examination, inquiry is allowable into relevant specific instances of conduct.

(b) Specific Instances of Conduct. In cases in which character or a trait of character of a person is an essential element of a charge, claim, or defense, proof may also be made of relevant specific instances of that person's conduct.

\section{RULE 5-406. HABIT; ROUTINE PRACTICE}

Evidence of the habit of a person or of the routine practice of an organization is relevant to prove that the conduct of the person or organization on a particular occasion was in conformity with the habit or routine practice.

\section{RULE 5-607. WHO MAY IMPEACH}

The credibility of a witness may be attacked by any party, including the party calling the witness.

\section{RULE 5-608. EVIDENCE OF CHARACTER OF WITNESS FOR TRUTHFULNESS OR UNTRUTHFULNESS}

\section{(a) Impeachment and Rehabilitation by Character Witnesses.}

(1) Impeachment by a Character Witness. In order to attack the credibility of a witness, a character witness may testify (A) that the witness has a reputation for untruthfulness, or (B) that, in the character witness's opinion, the witness is an untruthful person.

(2) Rehabilitation by a Character Witness. After the character for truthfulness of a witness has been attacked, a character witness may testify (A) that the witness has a good reputation for truthfulness or (B) that, in the character witness's opinion, the witness is a truthful person. 
(3) Limitations on Character Witness's Testimony.

(A) A character witness may not testify to an opinion as to whether a witness testified truthfully in the action.

(B) On direct examination, a character witness may give a reasonable basis for testimony as to reputation or an opinion as to the character of the witness for truthfulness or untruthfulness, but may not testify to specific instances of truthfulness or untruthfulness by the witness.

(4) Impeachment of a Character Witness. The court may permit a character witness to be cross-examined about specific instances in which a witness has been truthful or untruthful or about prior convictions of the witness as permitted by Rule 5-609. Upon objection, however, the court may permit the inquiry only if (A) the questioner, outside the hearing of the jury, establishes a reasonable factual basis for asserting that the prior instances occurred or that the convictions exist, and (B) the prior instances or convictions are relevant to the witness's reputation or to the character witness's opinion, as appropriate.

(b) Impeachment by Examination Regarding Witness's Own Prior Conduct Not Resulting in Convictions. The court may permit any witness to be examined regarding the witness's own prior conduct that did not result in a conviction but that the court finds probative of a character trait of untruthfulness. Upon objection, however, the court may permit the inquiry only if the questioner, outside the hearing of the jury, establishes a reasonable factual basis for asserting that the conduct of the witness occurred. The conduct may not be proved by extrinsic evidence.

(c) Effect on Privilege Against Self-Incrimination. The giving of testimony, whether by an accused or by any other witness, does not operate as a waiver of the witness's privilege against self-incrimination when examined with respect to matters which relate only to credibility.

Committee note: This Rule does not address proof of specific instances of conduct when offered on some theory other than impeachment by past acts indicative of a character trait of untruthfulness, such as evidence bearing on bias, interest, hostility, motive to misrepresent, or inability to observe, remember, or narrate. It also does not address the admissibility of evidence under the "opened door" theory.

\section{RULE 5-609. IMPEACHMENT BY EVIDENCE OF CONVICTION OF CRIME}

(a) Generally. For the purpose of attacking the credibility of a witness, evidence that the witness has been convicted of a crime shall be admitted if elicited from the witness or established by public record during examination of the witness, but only if (1) the crime was an infamous crime or other crime relevant to the witness's credibility and (2) the court determines that the probative value of admitting this evidence outweighs the danger of unfair prejudice to the witness or the objecting party.

Cross reference: Code, Courts Article, $\S 10-905$

Committee note: The requirement that the conviction, when offered for purposes of impeachment, be brought out during examination of the witness is for the protection of the witness. It does not apply to impeachment by evidence of prior conviction of a hearsay declarant who does not testify. 
(b) Time Limit. Evidence of a conviction is not admissible under this Rule if a period of more than 15 years has elapsed-since the date of the conviction.

(c) Other Limitations. Evidence of a conviction otherwise admissible under section (a) of this Rule shall be excluded if:

(1) the conviction has been reversed or vacated;

(2) the conviction has been the subject of a pardon; or

(3) an appeal or application for leave to appeal from the judgment of conviction is pending, or the time for noting an appeal or filing an application for leave to appeal has not expired.

(d) Effect of Plea of Nolo Contendere. For purposes of this Rule, "conviction" includes a plea of nolo contendere followed by a sentence, whether or not the sentence is suspended.

Committee note: See Code, Courts Article, § 3-824 for the effect of juvenile adjudications and for restrictions on their admissibility as evidence generally. Evidence of these adjudications may be admissible under the Confrontation Clause to show bias; see Davis v. Alaska, 415 U.S. 308 (1974).

\section{RULE 5-616. IMPEACHMENT AND REHABILITATION-GENERALLY}

(a) Impeachment by Inquiry of the Witness. The credibility of a witness may be attacked through questions asked of the witness, including questions that are directed at:

(1) Proving under Rule 5-613 that the witness has made statements that are inconsistent with the witness's present testimony.

(2) Proving that the facts are not as testified to by the witness;

(3) Proving that an opinion expressed by the witness is not held by the witness or is otherwise not worthy of belief;

(4) Proving that the witness is biased, prejudiced, interested in the outcome of the proceeding, or has a motive to testify falsely;

(5) Proving lack of personal knowledge or weaknesses in the capacity of the witness to perceive, remember, or communicate; or

(6) Proving the character of the witness for untruthfulness by (i) establishing prior bad acts as permitted under Rule 5-608(b) or (ii) establishing prior convictions as permitted under Rule 5-609.

(b) Extrinsic Impeaching Evidence.

(1) Extrinsic evidence of prior inconsistent statements may be admitted as provided in Rule 5-613(b).

(2) Other extrinsic evidence contradicting a witness's testimony ordinarily may be admitted only on non-collateral matters. In the court's discretion, however, extrinsic evidence may be admitted on collateral matters. 
(3) Extrinsic evidence of bias, prejudice, interest, or other motive to testify falsely may be admitted whether or not the witness has been examined about the impeaching fact and has failed to admit it.

(4) Extrinsic evidence of a witness's lack of personal knowledge or weaknesses in the capacity of the witness to perceive, remember, or communicate may be admitted if the witness has been examined about the impeaching fact and has failed to admit it, or as otherwise required by the interests of justice.

(5) Extrinsic evidence of the character of a witness for untruthfulness may be admitted as provided in Rule 5-608.

(6) Extrinsic evidence of prior convictions may be admitted as provided by Rule 5-609.

(7) Extrinsic evidence may be admitted to show that prior consistent statements offered under subsection (c)(2) of this Rule were not made.

(c) Rehabilitation. A witness whose credibility has been attacked may be rehabilitated by:

(1) Permitting the witness to deny or explain impeaching facts, except that a witness who has been impeached by prior conviction may not deny guilt of the earlier crime;

(2) Except as provided by statute, evidence of the witness's prior statements that are consistent with the witness's present testimony, when their having been made detracts from the impeachment;

(3) Evidence through other witnesses of the impeached witness's character for truthfulness, as provided in Rule 5-608(a); or

(4) Other evidence that the court finds relevant for the purpose of rehabilitation.

\section{RULE 5-806. ATTACKING AND SUPPORTING CREDIBILITY OF DECLARANT}

(a) In General. When a hearsay statement has been admitted in evidence, the credibility of the declarant may be attacked, and if attacked may be supported, by any evidence which would be admissible for those purposes if the declarant had testified as a witness. Evidence of a statement or conduct by the declarant at any time, inconsistent with the declarant's hearsay statement, is not subject to any requirement that the declarant may have been afforded an opportunity to deny or explain. If the party against whom a hearsay statement has been admitted calls the declarant as a witness, the party is entitled to examine the declarant on the statement as if under cross-examination.

(b) Exception. This Rule does not apply to statements by party-opponents under Rule 5-803(a)(1) and (a)(2). 